\title{
Estimating Agricultural Losses using Flood Modeling for Rural Area
}

\author{
Nur Atirah Muhadi ${ }^{3,}$, Ahmad Fikri Abdullah ${ }^{3}$, and Zoran Vojinovic ${ }^{1,2}$ \\ ${ }^{1}$ UNESCO-IHE, Westvest 7, 2611 AX Delft, The Netherlands \\ ${ }^{2}$ University of Exeter, EX4 4QF, UK \\ ${ }^{3}$ Department of Biological and Agricultural Engineering, Faculty of Engineering, Universiti Putra \\ Malaysia, 43400 Serdang, Selangor, Malaysia
}

\begin{abstract}
Flooding is the most significant natural hazard in Malaysia in terms of population affected, frequency, flood extent, flood duration and social economic damage. Flooding causes loss of lives, injuries, property damage and leave some economic damage to the country especially when it occurs in a rural area where the main income is dependent on agricultural area. This study focused on flooding in oil palm plantations, rubber plantations and fruits and vegetables area. InfoWorks ICM was used to develop a flood model to study the impact of flooding and to mitigate the floods using a retention pond. Later, Geographical Information System (GIS) together with the flood model were used for the analysis on flood damage assessment and management of flood risk. The estimated total damage for three different flood event; 10 ARI, 50 ARI and 100 ARI involved millions of ringgits. In reducing the flood impact along the Selangor River, retention pond was suggested, modeled and tested. By constructing retention pond, flood extents in agricultural area were reduced significantly by $60.49 \%$ for 10 ARI, $45.39 \%$ for 50 ARI and $46.54 \%$ for 100 ARI.
\end{abstract}

\section{Introduction}

Flood is one of the major severe natural catastrophes experiencing in many countries around the world and the researchers and practitioners are challenged with urbanization, population growth and climate change and finding optimal flood protection and system rehabilitation strategies [1-8]. The process of preparing for such disasters requires investments in data and models. However the benefits of numerical models and data will depend on a number of issues such as the accuracy of the data and uncertainties [9-20]. The basic causes of flood in Malaysia are the incidence of heavy monsoon rainfall and the large concentration of runoff, which exceeds river capacity [21, 22]. Agricultural lands located in catchment areas have the highest probability to involve in flood events especially for those reside in low land area [23]. Flood damages can be categorized into tangible and intangible damages. Tangible damage can be calculated in monetory terms meanwhile intangible cannot be easily measured in monetory terms [24-26].

\footnotetext{
*Corresponding author: tiramuhadi@gmail.com
} 
In disaster management strategies, several steps are needed in order to identify risks and making decision on the most appropriate measures with risk assessment is claimed to be the important part of the process [27]. Mitigation is another step required in disaster management strategies. The aim of flood mitigation is to reduce the long term impacts of disasters on a nation or community. Flood mitigation refers to any structural or nonstructural measures taken to reduce the flooding impacts. Bustami and collegues [28] carried out a study for modeling of flood mitigation structures in Sarawak River sub-basin. It is reported that retention ponds provide the most efficient in mitigating the flood condition of the study area. In order to study the impact of flooding, a flood model is developed. Flood model will help in estimating the flood inundation for rural area. To meet the purpose, InfoWorks Integrated Catchment Modeling (ICM) was used to develop a comprehensive flood model that covers main river and floodplain. Results from the model was then used to carry out relevant analysis on flood damage assessment. In addition, InfoWorks ICM is also used to run simulation on certain scenarios on mitigation options. Besides, Geographical Information System (GIS) in combination with appropriate flood models provide ideal tools for the analysis and management of flood risk. GIS overlays of the land use and the flood extent are used to study the impact of flooding in the study area.

\section{Method}

\subsection{Study area and data collection}

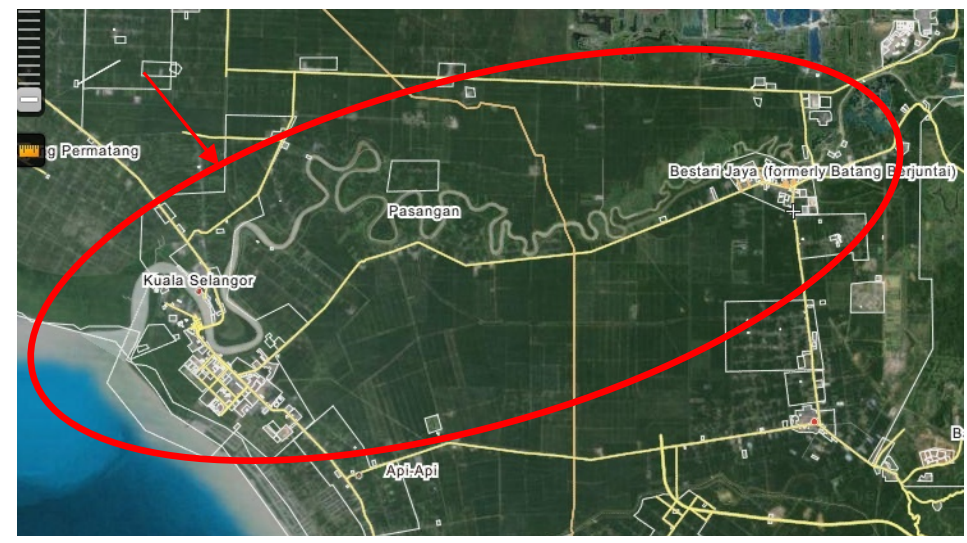

Fig. 1. Location of the study area

This study has been carried out in a rural area located in Selangor river basin. However, only several parts of the Selangor River are involved which are Kuala Selangor, Pasangan and Bestari Jaya. Fig. 1 shows the location of the study area. There are two types of data required for this study, which are spatial data and non-spatial data. Spatial data include topographic data and land use data while non-spatial data includes rainfall intensity and river water level. In order to develop a good InfoWorks ICM model, good quality of GIS data of the catchment and good quality of digital elevation models (DEMs) data to represent natural depressions and embankments on the ground are required. Terrain is analyzed to avoid lands with steep slopes above permitted limits while regional watershed studies are performed to identify flood-prone areas. In this study, IFSAR data were used in developing the DEM for flood model. IFSAR data are best used in sparsely vegetated areas with relatively low slopes and away from urban areas. IFSAR data are appropriate for watershed-scale analysis. Because of its wider swath and greater flying speeds, IFSAR are 
more appropriate and more cost effective for large area applications. IFSAR is used in creating elevation models of the terrain from airborne platforms at superior levels of spatial detail typically 1-5 meters sample spacing and accuracy which is $15 \mathrm{~cm}-3$ meters RMSE vertical [29].

\section{Results}

In a report of Water Resources Planning Institute of Vietnam, it is suggested to use a 10 ARI as a flood standard for agricultural flood protection activities [30]. In addition, 100 ARI has been universally used to describe a reasonable flood protection level. Therefore, this study used three flood scenarios which are 10 ARI, 50 ARI and 100 ARI to assess the impacts of floods on agriculture in the Selangor river basin area. The model predicts the flood depth and flood extent for the 10 ARI, 50 ARI and 100 ARI scenarios and these are presented in Fig. 3 for 10 ARI flood depth. Table 1 represents the total inundated area during the flood events. The model predicts the areas of flood extents and flood depths for each of the flood scenarios. Hence, the proportions of the flood depth were calculated for each flood scenario. As a result of the flood model simulations, more than $40 \%$ of the total flood extent was covered by $1.2 \mathrm{~m}$ flood depth for each 10 ARI, 50 ARI and 100 ARI. Only area that will be flooded by 0.5 to $1.2 \mathrm{~m}$ of floods will be calculated during the analysis. The $0.001 \mathrm{~m}$ depth is not a severe flood thus it is not accounted as flood for this study. Table 1 also shows the total inundated area based on flood depth for each flood event.

Table 1. Total inundated area based on flood depth

\begin{tabular}{|c|c|c|c|}
\hline \multirow{2}{*}{ Flood Depth (m) } & \multicolumn{3}{|c|}{ Total Inundated Area (ha) } \\
\cline { 2 - 4 } & 10 ARI & 50 ARI & 100 ARI \\
\hline 0.001 & 1477.41 & 2204.07 & 2336.78 \\
\hline 0.5 & $\mathbf{1 8 6 6 . 4 2}$ & $\mathbf{2 7 9 2 . 5 1}$ & $\mathbf{3 0 7 4 . 1 5}$ \\
\hline 1.2 & $\mathbf{2 5 0 2 . 5 2}$ & $\mathbf{4 1 7 6 . 9 9}$ & $\mathbf{4 7 6 7 . 4 6}$ \\
\hline Total & 5846.35 & 9173.57 & 10178.39 \\
\hline
\end{tabular}

The flood risk maps resulted from the flood model was overlaid with the land use maps to assess the impact of 10 ARI, 50 ARI and 100 ARI in the study area. Fig. 2 shows the results for three various return periods which are overlaid with land use map. Different return periods have different flood extents. Among all types of land used, the model estimates that the greatest land use impacted by the floods is the agricultural land.

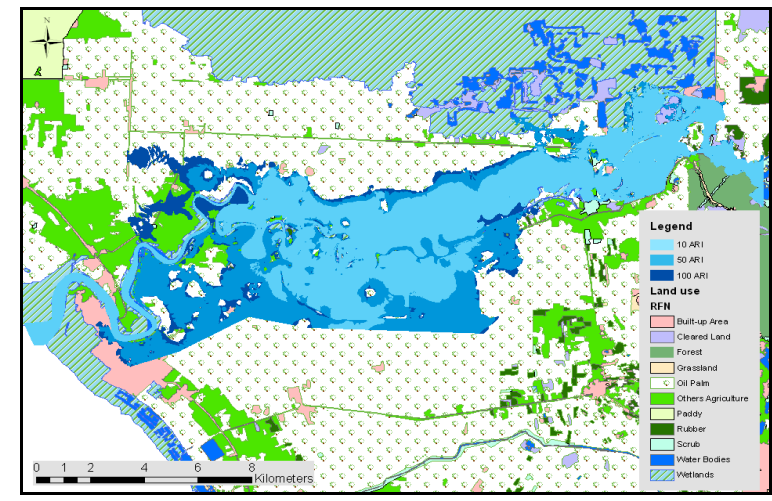

Fig. 2. The results for $10 \mathrm{ARI}, 50 \mathrm{ARI}$ and $100 \mathrm{ARI}$ 


\subsection{Floods in Agricultural Sector}

Based on agricultural cycle, excessive rainfall is detrimental to crops as yield is significantly affected, especially in oil palm and rubber plantations. Table 2 shows the estimated agricultural land that the model predicts to be affected.

Table 2. Estimated area of agricultural land affected by flood scenarios

\begin{tabular}{|c|c|c|c|}
\hline \multirow{2}{*}{ Flood Scenario } & \multicolumn{3}{|c|}{ Flooded area (ha) } \\
\cline { 2 - 4 } & 10 ARI & 50 ARI & 100 ARI \\
\hline Oil palm & 1759.97 & 3642.32 & 4249.62 \\
\hline Rubber & 39.68 & 70.41 & 79.39 \\
\hline Other agriculture & 260.76 & 576.19 & 657.19 \\
\hline $\begin{array}{c}\text { Total flooded in } \\
\text { agricultural area }\end{array}$ & $\mathbf{2 0 6 0 . 4 1}$ & $\mathbf{4 2 8 8 . 9 2}$ & $\mathbf{4 9 8 6 . 2 0}$ \\
\hline Total flooded area & 5846.35 & 9173.57 & 10178.40 \\
\hline
\end{tabular}

The predicted flooded in agricultural areas for the 10 ARI, 50 ARI and 100 Ari scenarios are estimated to be 2060.41 ha, 4288.92 ha and 4986.2 ha respectively, which accounts for $47 \%, 62 \%$ and $64 \%$ respectively, of the total inundated area. The highest area affected by the floods is oil palm plantations, followed by the mixture of various types of agricultural crop and rubber plantations.

\subsection{Estimation of Direct Flood Losses in Oil Palm Plantation}

In order to simplify the calculation of losses in oil palm plantations, this study assumed that all oil palm trees were in the same maturity and they were in the early stage of growth. Besides, this study postulated that once the oil palm plantations are flooded, all the oil palm trees are damaged and cannot be harvested, so the worst case scenario is chosen. The average monthly Fresh Fruit Bunch (FFB) yields reported from Malaysian Palm Oil Board (MPOB) for March 2014 in Selangor state was 1.39 tonnes/hectare [31]. The reference price for FFB at the mill gate on March 18, 2014 is $634 \mathrm{RM} /$ tonne [32]. This reference price was chosen because the simulation of flood model was carried out on March 18, 2014. The total loss on oil palm plantations for three flood events involved millions of ringgits. Table 3 shows the total area affected, total FFB and total price loss for each return period.

Table 3. The losses in oil palm plantations for each return period

\begin{tabular}{|c|c|c|c|}
\hline $\begin{array}{c}\text { Flood Event } \\
\text { (years ARI) }\end{array}$ & $\begin{array}{c}\text { Total Area } \\
\text { (ha) }\end{array}$ & $\begin{array}{c}\text { Total FFB } \\
\text { (tonnes) }\end{array}$ & $\begin{array}{c}\text { Total Price Loss (million } \\
\text { RM) }\end{array}$ \\
\hline 10 & 1759.97 & 2446.36 & 1.55 \\
\hline 50 & 3642.32 & 5062.82 & 3.21 \\
\hline 100 & 4249.62 & 5906.97 & 3.75 \\
\hline
\end{tabular}

\subsection{Estimation of Direct Flood Losses in Rubber Plantation}

Department of Statistics reported in the Monthly Rubber Statistics Malaysia [33] that the productivity of natural rubber in February 2014 was recorded at 129.1 kilogram per hectare. The prices of the rubber at the farm gate on March 18, 2014 were 510 cents $/ \mathrm{kg}$ for low ammonia rubber and 605 cents/kg for rubber which contains high ammonia [33]. This study assumed that all the rubber trees in the study areas were in the same age and they will damage during floods. These assumptions are important in order to simplify the 
calculations of the rubber losses. Table 4 shows the total losses in rubber plantations during floods.

Table 4. The total losses in rubber plantations during floods

\begin{tabular}{|c|c|c|c|c|}
\hline \multirow{2}{*}{$\begin{array}{c}\text { Flood Event } \\
\text { (years ARI) }\end{array}$} & \multirow{2}{*}{$\begin{array}{c}\text { Total Area } \\
\text { (ha) }\end{array}$} & \multirow{2}{*}{ Total NR (kg) } & \multicolumn{2}{|c|}{ Total Price (thousands RM) } \\
\cline { 3 - 5 } & & Low & High \\
\hline 10 & 39.68 & 5122.69 & 26.13 & 30.99 \\
\hline 50 & 70.41 & 9089.93 & 46.36 & 54.99 \\
\hline 100 & 79.39 & 10249.25 & 52.27 & 62.01 \\
\hline
\end{tabular}

\subsection{Flood Mitigation Structure in the Study Area}

Mitigation is a strategy to reduce the long term impacts of disasters face by a nation or community. Flood mitigation refers to any structural or non-structural measures taken to reduce the flooding impacts. The flood mitigation structure proposed in this study was a retention pond. The retention pond was chosen because it is used to collect storm water runoff for the purpose of controlling of this runoff and it has been proved to be the effective mitigation option to reduce flood. The retention pond is located at an appropriate location along the Selangor River. It is located at $101^{\circ} 24^{\prime} 23.839 " \mathrm{E}$ and $3^{\circ} 25^{\prime} 57.396 " \mathrm{~N}$. The retention pond was built in a lower area so that water can easily flow from higher to lower land and go into the pond. This decision was made in order to reduce cost.

By building the retention pond in lowland, the cost of making sure the water flows go into the pond is reduced. Furthermore, the pond was built in an abandoned mine area which is located in Bestari Jaya. This location was chosen to ensure that the location of building the pond does not involve other residents. If the location of the retention pond has land owners, the cost of building the retention pond increases because the authorities have to pay for compensation for building on people's lands. The area of the retention pond is 341.5 ha. The depth of the retention pond is 8 meters depth. The size of the retention pond was determined based on the volume for 10 ARI, 50 ARI and 100 ARI. The retention pond can store only 2732 ha-m or $27,000,000 \mathrm{~m}^{3}$ of water. Thus, this pond cannot store all the excessive water flows during the 10 ARI, 50 ARI and 100 ARI because the total volumes for these three various return periods are 3936.24 ha-m, 6408.65 ha-m and 7258.03 ha-m respectively. However, it can help in reducing the impacts of flood as it reduces the flood depths and flood extents. After the input of the retention pond was made, the simulations of the model were re-run to study the scenarios of the flood after being mitigated. Table 5 shows the area that will be flooded before and after flood mitigation and percentage reduced after flood mitigation is done.

Table 5. The percentages reduced in the study area after using flood mitigation structure

\begin{tabular}{|c|c|c|c|c|c|c|}
\hline $\begin{array}{c}\text { Flood } \\
\text { Event } \\
\text { (years } \\
\text { ARI) }\end{array}$ & $\begin{array}{c}\text { Area Before } \\
\text { Mitigation } \\
\text { (ha) }\end{array}$ & $\begin{array}{c}\text { Area After } \\
\text { Mitigation } \\
\text { (ha) }\end{array}$ & $\begin{array}{c}\text { Percentage } \\
\text { Reduced } \\
\text { (\%) }\end{array}$ & $\begin{array}{c}\text { Volume } \\
\text { Before } \\
\text { Mitigation } \\
\text { (ha) }\end{array}$ & $\begin{array}{c}\text { Volume } \\
\text { After } \\
\text { Mitigation } \\
\text { (ha) }\end{array}$ & $\begin{array}{c}\text { Percentage } \\
\text { Reduced } \\
\text { (\%) }\end{array}$ \\
\hline 10 & 4368.94 & 2642.93 & 60.49 & 3936.24 & 2574.87 & 65.41 \\
\hline 50 & 6969.5 & 3163.09 & 45.39 & 6408.65 & 3086 & 48.15 \\
\hline 100 & 7841.61 & 3649.29 & 46.54 & 7258.03 & 3464.17 & 47.73 \\
\hline
\end{tabular}

From the table, it is clearly shown that the retention pond helps in reducing the flood extent in the study area. Besides the reducing in flood extent, retention pond can also 
reduce the flood impact in term of flood depth. Table 6 also represents the decreasing in volume after applying flood mitigation condition in the study area. The decreasing in volume is due to the decreasing in flood depth and flood extent. The flood depth of the flooded area may not reduce in term of the flood height, but it reduces in term of flood coverage. To assess the flood damage more clearly, the flood maps were overlaid with the land use map. After the flood mitigation, the estimated flooded area in the agricultural area has been reduced. The floods cover oil palm area, rubber area, others agriculture area, builtup area, wetlands, water bodies and a few scrub, cleared land, and grassland.

\subsection{Floods in Agricultural Sector after Mitigation}

Even though the flooded area in agricultural land is reduced, the agricultural plantations are still affected by the floods. Table 6 shows the estimated agricultural land that the model predicts to be affected. The most affected area during flooding event is oil palm plantations, followed by the mixture of various types of agricultural crops and rubber plantation. These results are the same as the results before applying flood mitigation.

Table 6. Estimated area of agricultural land affected by flood scenarios after flood mitigation is done

\begin{tabular}{|l|c|c|c|c|c|c|}
\hline \multirow{2}{*}{ Flood Scenario } & \multicolumn{3}{|c|}{ Flooded area (ha) } & \multicolumn{3}{c|}{ Total Losses (million RM) } \\
\cline { 2 - 7 } & $\mathbf{1 0}$ ARI & 50 ARI & 100 ARI & 10 ARI & 50 ARI & 100 ARI \\
\hline Oil palm & 620.7 & 903.12 & 1193.58 & 0.55 & 0.80 & 1.05 \\
\hline Rubber & 15.35 & 23.42 & 32.09 & 0.010 & 0.015 & 0.021 \\
\hline $\begin{array}{l}\text { Other } \\
\text { agricultural }\end{array}$ & 73.45 & 95.23 & 145.16 & & & \\
\hline $\begin{array}{l}\text { Total flooded in } \\
\text { agricultural area }\end{array}$ & 709.50 & 1021.77 & 1370.83 & & & \\
\hline
\end{tabular}

\section{Conclusion}

This study presented an overview of flood mapping and GIS technology in order to determine the flood losses on agricultural land along the Selangor River. The impacts were determined in term of the price losses when the areas are flooded by three different flood event; 10 ARI, 50 ARI and 100 ARI. The flood damage during each flood events was calculated in the oil palm plantation area and rubber plantations. The total flooded area of agricultural land for 10 ARI was 2060.41 ha, 4288.92 ha for 50 ARI and 4986.20 ha for 100 ARI. The estimated total damage for these three return periods involved millions of ringgits. The calculated damage in agricultural area for 10 ARI was nearly RM2, 510,000 meanwhile for 50 ARI was RM5, 320,000. The highest damage was RM6, 150,000 during 100 ARI. An appropriate flood mitigation structure which was retention pond, in reducing the flood scenarios along the Selangor River was suggested, modeled and tested. The effects of the retention ponds were analyzed and evaluated for 10 ARI, 50 ARI and 100 ARI. By implementing retention pond, flood damage in agricultural area were reduced significantly by $67.33 \%$ for 10 ARI, $78.33 \%$ for 50 ARI and $74.14 \%$ for 100 ARI. It was found that the flood mitigation benefits in reducing the total flood damage in agricultural area for more than three million ringgits. This value is just an underestimation of the actual flood mitigation benefits as there are some assumptions made during the process of calculating the flood damage. Besides reducing the impacts of the floods in the study area, the flood mitigation can help in reducing the losses that country may face and the losses of the farmers' income. Other measures that can be used to overcome flood problem are by improving flood warning system so that people can have enough time to take action when 
flood occurs and by preserving wetlands and forestry which can act as sponges when flood overflows.

\section{References}

[1] W. Barreto, Z. Vojinovic, R. Price and D. Solomatine, Multi objective evolutionary approach to rehabilitation of urban drainage systems. J. water resour. plan. manage., 136, 547-554, (2009)

[2] D.S. Kumar, D.S Arya and Z. Vojinovic, Modeling of urban growth dynamics and its impact on surface runoff characteristics, Comput Environ Urban Syst., 41, 124-135, (2013)

[3] A. Mynett and Z. Vojinovic, Hydroinformatics in multi-colours - part red: Urban Flood and Disaster Management, J. Hydroinform, 11, 166-180, (2009)

[4] Z. Vojinovic and J. van Teeffelen, An Integrated Stormwater Management Approach for Small Islands in Tropical Climates, Urban Water J., 4, 211 - 231, (2007)

[5] Z. Vojinovic, D.P. Solomatine and R.K. Price, Dynamic Least-Cost Optimisation of Wastewater System Remedial Works Requirements, Water Sci Technol., 54, 467-475, (2006)

[6] Z. Vojinovic, S. Sahlu, S. Seyoum, A. Sanchez, H. Matungulu, Z. Kapelan and D. Savic, Multi-objective rehabilitation of urban drainage systems under uncertainties, J. Hydroinform, 16, 1044-1061, (2014)

[7] A. Sanchez, N. Medina, Z. Vojinovic and R. Price, An integrated cellular automata evolutionary-based approach for evaluating future scenarios and the expansion of urban drainage networks, J, Hydroinform, 16, 319-340, (2014)

[8] Z. Vojinovic and A. Sanchez, Optimising Sewer System Rehabilitation Strategies between Flooding, Overflow Emissions and Investment Costs, 11th Int. Conf. on Urban Drainage, Edinburgh, Scotland, (2008)

[9] A. Abdullah, A. Rahman and Z. Vojinovic, LiDAR filtering algorithms for urban flood application: Review on current algorithms and filters test. Laserscanning 09, 38, 30-36, (2009)

[10] A.F. Abdullah, Z. Vojinovic and R.K Price, A Methodology for Processing Raw LIDAR Data to Support 1D/2D Urban Flood Modelling Framework, J. Hydroinform, 4, 75-92,(2011)

[11]A.F. Abdullah, Z. Vojinovic, R.K and Price, Improved Methodology for Processing Raw LIDAR Data to Support Urban Flood Modelling - Accounting for Elevated Roads and Bridges, J. Hydroinform, 14, 253-269, (2011)

[12] V. Meesuk, Z. Vojinovic, A. Mynett and A.F. Abdullah, Urban flood modelling combining top-view LiDAR data with ground-view SfM observations, Adv Water Resour 75, 105-117, (2015)

[13] S.D. Seyoum, Z. Vojinovic, R.K Price and S. Weesakul, Coupled 1d and non-inertia 2d flood inundation model for simulation of urban pluvial flooding, J. Hydraul. Eng.ASCE, 138, 23-34, (2012)

[14]Z. Vojinovic, S. Seyoum, M.H. Salum, R.K Price, A.F. Fikri and Y. Abebe, Modelling floods in urban areas and representation of buildings with a method based on adjusted conveyance and storage characteristics, J. Hydroinform, 15, 1150-1168, (2012)

[15]Z. Vojinovic and D. Tutulic, On the use of 1D and coupled 1D-2D approaches for assessment of flood damages in urban areas, Urban Water J., 6, 183-199, (2009) 
[16]Z. Vojinovic and M.B. Abbott, Flood Risk and Social Justice: From Quantitative to Qualitative, Flood Risk Assessment and Mitigation, 2, (2012)

[17]Z. Vojinovic, M. Hammond, D. Golub, S. Hirunsalee, S. Weesakul, V. Meesuk and M. Abbott, Holistic approach to flood risk assessment in areas with cultural heritage: a practical application in Ayutthaya, Thailand. Natural Hazards, 81, 589-616, (2016)

[18]Z. Vojinovic, S.D. Seyoum, J.M. Mwalwaka and R.K. Price, Effects of Model Schematization, Geometry and Parameter Values on Urban Flood Modelling, Water Sci Technol., 63, 462-467, (2011)

[19]Z. Vojinovic, B. Bonillo, K. Chitranjan and R. Price, Modelling flow transitions at street junctions with 1D and 2D models, 7th Int. Conf. on Hydroinformatics, (2006)

[20] M.B. Abbott, B.M. Tumwesigye and Z. Vojinovic, The fifth generation of modelling in Hydroinformatics, 7th Int. Conf. on Hydroinformatics, (2006)

[21] K. H. Ho, A. H. Ghazali and S. F. Chong, Calibration and evaluation of modified tank model (flood forecasting model) for Kelantan river basin, Malaysia, Proc. of the water Eng. Conf. Malaysia, 23-24, (2002)

[22] M. E. Toriman and M. N. Shukor, An Analysis of Rainfall Interception on the selection Experimental Plot of Pangkor Hill Reserved Forest. J. of Wildlife and Parks, 22(2), 169-178, (2007).

[23] A.H. Thieken, V. Ackermann, F. Elmer, H. Kreibich, B. Kuhlmann, U. Kunert and J. Schwarz, Methods for the evaluation of direct and indirect flood losses, Proc. of the 4th Int. Sym. on Flood Defence: Managing Flood Risk, Reliability and Vulnerability, Toronto, ON, Canada, 68, 110, (2008)

[24]E. Genovese, A methodological approach to land use-based flood damage assessment in urban areas: Prague case study. Technical EUR Reports, EUR, 22497, (2006)

[25] L. C. P. M. Stuyt, J. E. A. Reinders, E. E. Van Der Hoek, E. G. M. Hermans, M. M. De Keizer and J. Icke, The Environmental Impact of Flooding of The Dutch 'DeltaMetropole', Flood Risk Management in Europe, 107-129, (2007)

[26]Z. Vojinovic, J. D. W. Ediriweera and A. Fikri, An approach to the model-based spatial assessment of damages caused by urban floods, 11th Int. Conf. on Urban Drainage, 31 (2008).

[27]R. K. Price and Z. Vojinovic, Urban flood disaster management, Urban Water J., 5, 259-276, (2008)

[28] R. Bustami, C. Bong, D. Mah, A. Hamzah and M. Patrick, Modeling of Flood Mitigation Structures for Sarawak River Sub-basin Using InfoWorks River Simulation (RS), World Acad Sci Eng Technol., 14-18, (2009)

[29]B. Mercer, Comparing LIDAR and IFSAR: What can you expect, Proc. of Photogrammetric Week, (2001)

[30] Institute of Water Resources Planning (IWRP), Review and update the flood prevention plan for central provinces: Vu Gia-Thu Bon river, Institute of Water Resources Planning, Hanoi, (2001)

[31] Malaysian Palm Oil Board (MPOB), MPOB Monthly Prices of Palm Oil Products Traded In March 2014 (RM/TONNE), Retrieved on April 7, 2014 from http://www.mpoc.org.my/

[32] Malaysian Palm Oil Board (MPOB), Monthly FFB Yield (Tonnes/Hectare), Retrieved on April 7, 2014 from http://www.mpoc.org.my

[33] Malaysian Rubber Board. Natural Rubber Statistics 2014, Retrieved on April 7, 2014 from http://www.lgm.gov.my 